\author{
rie \\ Vol. 6 No. 1 Tahun 2020 \\ Bjoconcetta \\ Jurnal Biologi dan Pendidikan Biologi \\ ISSN: 2460-8556/E-ISSN:2502-1737 \\ Website: ejournal.stkip-pgri-sumbar.ac.id/index.php/BioCONCETTA
}

\title{
DETEKSI CEMARAN BAKTERIOLOGIS DAN LOGAM BERAT DAGING LANGKITANG (Faunus ater)
}

\section{DETECTION OF BACTERIOLOGICAL CONTAMINATION AND HEAVY METAL IN LANGKITANG (Faunus ater) MEAT}

\author{
Yosmed Hidayat*, Erismar Amri dan Irma Siska \\ Program Studi Pendidikan Biologi STKIP PGRI Sumatera Barat \\ J1. Gunung Pangilun Padang, Sumatera Barat (25137) Indonesia \\ Email: yosmedhidayat2@gmail.com
}

\section{Info Artikel \\ Sejarah Artikel \\ Diterima: \\ 08 Juli 2020 \\ Disetujui: \\ 09 Juli 2020 \\ Dipublikasikan: \\ 31 Juli 2020 \\ Kata Kunci: \\ Uji bakteriologis, Coliform, Faunus ater}

Keywords: Bacteriological Test, Coliform, Faunus ater

\begin{abstract}
Abstrak
Penelitian ini bertujuan untuk mengetahui tingkat cemaran bakteriologis dan logam berat Timbal ( $\mathrm{Pb}$ ) pada daging langkitang (Faunus ater). Pengambilan sampel dilakukan secara acak sebanyak 15 sampel dari pedagang. Pemeriksaan cemaran mikroba daging langkitang menggunakan metoda serial dilution Most Probable Number $(M P N)$ yang terdiri atas tahap presumtif test, confirmed test dan completed test. Pengukuran kandungan logam berat Timbal dilakukan dengan menggunakan Spektrofotometri Serapan Atom (SSA). Hasil pengujian bakteriologis MPN/100 ml sampel menunjukkan daging langkitang yang diuji positif mengandung bakteri pencemar untuk setiap sampel yang diuji, dan juga terdeteksi kandungan logam Timbal, beberapa diantaranya memiliki nilai yang melebihi ambang batas. Berdasarkan hasil analisis, daging langkitang memiliki kandungan cemaran mikroba dan logam berat Timbal yang melampaui ambang batas kesehatan, sehingga dibutuhkan pengolahan yang tepat sebelum daging dikonsumsi.
\end{abstract}

\begin{abstract}
This study aims to determine the level of bacteriological contamination and heavy metal lead $(\mathrm{Pb})$ in langkitang (Faunus ater) meat. The sample were taken randomly as 15 samples from traders. Examination of microbial contamination in meat used a serial dilution method Most Probable Number $(M P N)$ consisting of the presumptive test, confirmed test, and completed test. Measurement of Lead Heavy Metal (Pb) content used Atomic Absorption Spectrophotometry (AAS). The result of bacteriological testing of the MPN/ $100 \mathrm{ml}$ sample showed that the tested Langkitang meat contained contaminating bacteria for each sample tested, and Lead metal was also detected, some of which had values that exceeded the threshold. Based on the results of the analysis, the langkitang meat has a microbial and lead metal contamination content that exceeds the health threshold so that it takes proper processing before the meat is consumed.
\end{abstract}

Bioconcetta 


\section{PENDAHULUAN}

Langkitang (Faunus ater) dari Kelas Gastropoda merupakan siput atau keong yang hidup di perairan tawar. Daging langkitang banyak dimanfaatkan sebagai sumber protein hewani. Biasanya langkitang banyak dijajakan disekitar lokasi wisata, pasar dan tempat-tempat keramaian lainnya. Hewan ini sering dijadikan aneka lauk pauk dan makanan cemilan oleh masyarakat.

Banyaknya masyarakat yang mengkonsumsi langkitang menjadikan bahan makanan ini memiliki nilai ekonomis yang perlu mendapatkan perhatian khusus, terutama dari segi kesehatan. Sebagai bahan makanan perlu dipastikan langkitang yang dikonsumsi telah memenuhi persyaratan kecukupan gizi dan aman untuk dikonsumsi. Menurut Wibawa (2008) keamanan makanan adalah kondisi dan upaya yang diperlukan untuk mencegah pangan dari kemungkinan cemaran biologis, kimia, dan benda lain yang dapat mengganggu dan membahayakan kesehatan manusia. Bahan pencemar pada makanan dapat berasal dari organisme atau unsur kimia yang terakumulasi dalam berbagai bentuk, diantaranya dapat berupa cemaran mikroba patogen dan logam berat.

Pencemaran langkitang oleh mikroba patogen ataupun logam berat dapat dipengaruhi oleh kondisi habitat dan cara organisme ini memperoleh nutrisi, dimana langkitang adalah salah satu organisme indikator yang keberadaannya di perairan dapat digunakan untuk mengukur kondisi lingkungan di sekitarnya (Zeswita dan Safitri, 2015). Langkitang biasanya hidup pada perairan dangkal yang tersusun atas substrat lumpur dan berpasir. Hewan ini menyaring (filter feeder) substrat untuk memperoleh bahan organik yang dibutuhkan. Menurut Febrita (2015) substrat lumpur sangat disukai Gastropoda karena banyaknya bahan organik mengendap pada partikel lumpur yang dijadikan sebagai sumber nutrisi.

Pada perairan tercemar kebiasaan hidup langkitang dapat menyebabkan terjadinya bioakumulasi daging langkitang dengan organisme patogen atau unsur polutan pencemar. Cemaran logam berat dapat berasal dari berbagai sumber seperti limbah rumah tangga, industri, pertanian, dan lainnya. Logam berat dalam keadaan terlarut seperti Timbal $(\mathrm{Pb})$ dapat terakumulasi di dalam tubuh suatu organisme dan tetap tinggal dalam jangka waktu lama sebagai racun (Ismarti dkk., 2015). Saenab dkk. (2014), menyatakan akumulasi logam berat pada langkitang dapat terjadi melalui kebiasaan makannya yang memanfaatkan bahan organik di dasar perairan.

Selain pencemaran logam berat, kondisi ini juga memberi peluang terjadinya pencemaran daging langkitang oleh mikroba patogen coliform fecal yang ada di perairan seperti Enterobakter, Escherichia coli, Salmonella sp., dan lainnya. Bakteri patogen yang mencemari daging dapat mengakibatkan berbagai penyakit seperti sakit perut, kram perut, muntah, diare, demam dan tipus yang sering juga disebut food borne disease (Utari, 2016).

Pengawasan cemaran mikroba dan logam berat pada makanan sangat penting dilakukan untuk menjamin perlindungan kesehatan konsumen. Namun dalam 
aplikasinya di masyarakat masih banyak beredar bahan makanan yang tidak terjamin kesehatannya karena ketidaktahuan dari sipembeli dan sipedagang. Salah satu adalah daging langkitang, karena rentan tercemar bakteri dan terkontaminasi logam berat dari makanan yang dikonsumsinya. Maka oleh sebab itu penting untuk mendeteksi dan menganalisis cemaran bakteriologis dan logam berat pada daging langkitang (Faunus ater).

\section{BAHAN DAN METODE}

Penelitian dilaksanakan pada Bulan Januari 2018 di Laboratorium Biologi STKIP PGRI Sumatera Barat dan Laboratorium Terpadu Kopertis Wilayah X Kota Padang Sumatera Barat.

Sampel langkitang (Faunus ater) diperoleh dari penjual makanan di sekitar Pantai Padang Kota Padang Sumatera Barat. Masing-masing sampel diambil sebanyak 200 g selanjutnya dibawa ke laboratorium untuk dilakukan pemeriksaan bakteriologis dan logam berat.

Pemeriksaan bakteriologis yang dilakukan adalah pengujian bakteri coliform fecal pada sampel menggunakan metoda serial dilution Most Probable Number (MPN) seri 9 tabung. Pada tahap presumtif test tabung reaksi yang telah dimasukkan tabung durham yang diisi 10 $\mathrm{mL}$ media $L B$ kemudian kombinasikan menjadi 3:3:3. Masing-masing kombinasi tabung dimasukkan sampel dengan urutan $10 \mathrm{~mL}, 1 \mathrm{~mL}$ dan $0,1 \mathrm{~mL}$. Biakan dimasukkan dalam inkubator pada suhu $37{ }^{\circ} \mathrm{C}$ dengan lama inkubasi hingga 48 jam. Hasil dinyatakan positif bila terdapat gelembung dalam tabung durham.
Confirmed test dilakukan dengan memasukkan $1 \mathrm{~mL}$ larutan dari tabung positif pada pengujian sebelumnya ke dalam $10 \mathrm{~mL}$ media $B G L B$ dan diinkubasi pada suhu $37^{\circ} \mathrm{C}$ selama 24 jam. Keberadaan coliform fecal ditandai dengan terbentuknya gelembung gas pada tabung durham. Completed test dilakukan dengan penanaman biakan sampel positif pada tahapan sebelumnya ke medium $E M B$. Koloni yang tumbuh berwarna kilat logam merupakan E. coli.

Pemeriksaan logam berat yang dilakukan pada daging langkitang adalah kandungan Timbal, dengan cara daging langkitang digerus halus kemudian dimasukkan ke dalam oven pada suhu $105{ }^{\circ} \mathrm{C}$ sampai kering. Selanjutnya sampel didinginkan dalam desikator selama 30 menit dan difurnes. Sampel ditambahkan pelarut $\mathrm{HNO}_{3} \quad 65 \%$ kemudian didestruksi. Selama proses pemanasan sampel ditambahkan $\mathrm{H}_{2} \mathrm{O}_{2}$ pa $30 \%$ sampai cairan menjadi jernih. Hasil destruksi didinginkan dan disaring dengan menggunakan kertas Whatman No. 42. Pengukuran absorbasi larutan Timbal dilakukan menggunakan Spektrofotometri Serapan Atom (SSA). Hasil diperoleh melalui perbandingan pengukuran serapan logam sampel dengan pengukuran blanko standar Timbal.

Pengamatan bakteriologi di hitung menggunakan tabel MPN kemudian ditampilkan menggunakan bentuk tabel dan dianalisis. Pengamatan cemaran logam berat diolah dengan segresi linier sehingga didapatkan kurva kalibrasi.

Untuk menentukan konsentrasi dalam sampel digunakan persamaan sebagai berikut. 
$\mathrm{M}=(\mathrm{C} . \mathrm{V} . \mathrm{F}) / \mathrm{B}$

Keterangan

M : kosentrasi logam dalam sampel (mg/Kg).

C : kosentrasi logam dalam nilai absorbansi $(\mathrm{mg} / \mathrm{L})$.

$\mathrm{V}$ : volume larutan dari hasil destruksi sampel (L).

$\mathrm{F}$ : faktor pengenceran

B : berat sampel yang didestruksi $(\mathrm{Kg})$.

\section{HASIL DAN PEMBAHASAN}

Hasil pengujian bakteriologis dan logam berat Timbal $(\mathrm{Pb})$ yang telah dilakukan terhadap masing-masing sampel daging langkitang (Faunus ater) dapat dilihat pada Tabel 1 .

Tabel 1. Hasil Pengujian Bakteriologis dan Cemaran Logam Timbal (Pb) pada Daging Langkitang

\begin{tabular}{ccc}
\hline Sampel Daging Langkitang & $\begin{array}{c}\text { Presumtif test MPN/100 ml } \\
\text { Sampel }\end{array}$ & Kandungan Timbal $(\mathrm{Pb}) \mathrm{mg} / \mathrm{Kg}$ \\
\hline P 1 & 1100 & 2,889 \\
P 2 & 1100 & 1,395 \\
P 3 & 46 & 1,132 \\
P 4 & 2400 & 1,168 \\
P 5 & 2400 & 3,363 \\
P 6 & 2400 & 0,843 \\
P 7 & 43 & 1,525 \\
P 8 & 2400 & 1,214 \\
P 9 & 2400 & 1,256 \\
P 10 & 240 & 1,671 \\
P 11 & 1100 & 2,054 \\
P 12 & 2400 & 1,956 \\
P 13 & 1100 & 1,824 \\
P 14 & 43 & 1,027 \\
P 15 & 2400 & 1,483 \\
\hline
\end{tabular}

Pada pengujian bakteriologis menunjukkan, sampel daging langkitang positif mengandung bakteri ditandai dengan medium $L B$ menjadi keruh dan terdapat gelembung gas pada tabung durham. Terbentuknya gelembung gas dalam tabung durham dan perubahan warna media menunjukkan telah terjadi fermentasi laktosa dalam media cair sebagai bentuk aktifitas mikroba yang terdapat pada sampel, sehingga menghasilkan gas. Katon dkk. (2020) menyatakan bakteri gram negatif seperti kelompok bakteri Coliform dapat memfermentasi laktosa yang kemudian dapat menghasilkan gas dan asam pada tabung reaksi.

Hasil pengujian bakteriologis MPN daging langkitang (Tabel 1) menunjukkan total bakteri Coliform telah melampaui baku mutu atau ambang batas yang telah ditetapkan berdasarkan peraturan Badan Pengawas Obat dan Makanan (BPOM) Nomor 13 Tahun 2019 dan Standar Nasional Indonesia (SNI) Tahun 2009 tentang batas maksimum cemaran mikroba dalam pangan olahan.

Pengujian bakteriologis pada tahap confirmative test menunjukkan bahwa umumnya pada daging langkitang terdeteksi keberadaan bakteri Coliform. Mikroba indikator bisa saja tidak bersifat patogen tetapi keberadaanya menandakan kehadiran mikroba patogen lainya. Umumnya mikroba indikator tidak muncul bila tidak ada patogen. Menurut Mujahid dkk. (2015) Coliform merupakan kelompok organisme yang umum digunakan sebagai indikator dalam pemantauan kualitas air. Organisme ini 
mewakili bakteri yang biasanya ada di saluran usus mamalia termasuk manusia.

Pada tahapan completed test umumnya koloni bakteri menunjukkan warna hijau metalik yang menandakan koloni bakteri Escherichia coli. Bakteri
E. coli digunakan sebagai indikator untuk menguji kualitas air minum. E. coli yang hidup di usus manusia dan mamalia lainya merupakan Coliform fecal. Kehadiran E.coli menunjukkan bahwa air itu terkontaminasi oleh kotoran.

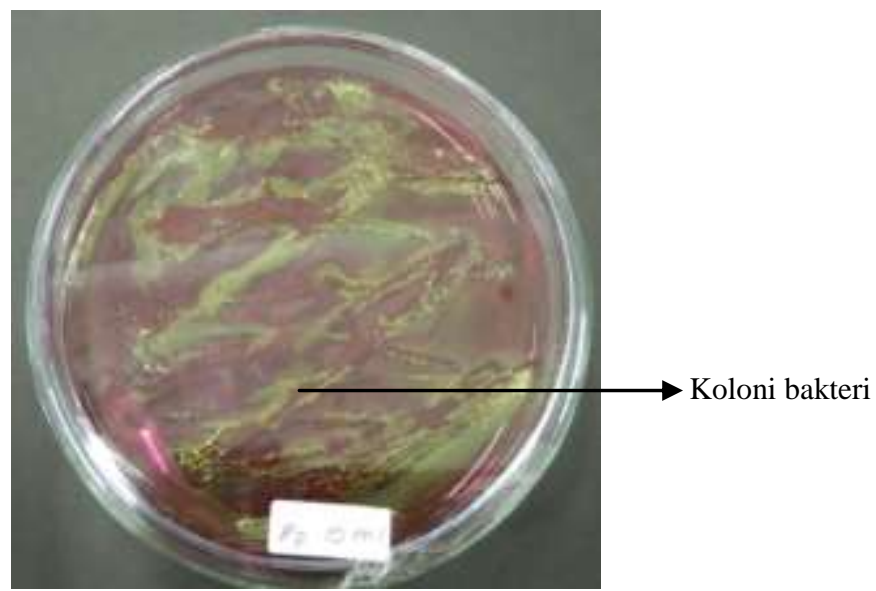

Gambar 1. Koloni bakteri E.coli pada medium EMB. Tampak bakteri berwarna hijau metalik/ kilat logam

Keberadaan bakteri pencemar pada daging langkitang bisa saja disebabkan bioakomulasi bakteri pencemar yang tersaring selama proses pengambilan makanan (filter fideer) diperairan. Organisme patogen yang hadir di lingkungan perairan dapat berasal dari alam atau mungkin juga berasal dari buangan manusia dan hewan berdarah panas lainnya (Mujahid dkk., 2015). Selain itu kontaminasi ini juga bisa disebabkan karena penumpukan daging langkitang selama berada di pengepul. Biasanya langkitang disimpan dalam karung yang berisi lumpur pasir dan ditumpuk dalam gudang dalam waktu cukup lama.

Tingginya kandungan air dan aktivitas air memungkinkan mikroba tumbuh sehingga cepat terjadi kerusakan. Kondisi fisik yang cocok mampu mendukung bakteri untuk tumbuh dan berkembang pada substrat. Menurut Megahati (2017) bakteri mampu bertahan hidup dan berkembang biak bila memiliki kisaran $\mathrm{pH}$ yang cocok. Beberapa mikroba patogen diketahui mampu hidup dan mencemari daging antara lain Escherichia coli, Salmonella sp., dan Staphylococcus sp., (Werdiningsih dkk., 2014).

Pada pengujian cemaran logam berat diketahui bahwa semua sampel daging langkitang mengandung timbal $(\mathrm{Pb})$ dengan jumlah bervariasi. Dari semua sampel yang diuji 7 sampel diketahui telah melewati ambang batas cemaran logam berat. Menurut Standar Nasional Indonesia (2008) batas maksimum cemaran logam timbal $(\mathrm{Pb})$ pada gastropoda dan jenis kerangkerangan sebesar $1,5 \mathrm{mg} / \mathrm{kg}$. Tingginya cemaran logam berat pada daging langkitang tentu akan memberikan 
dampak negatif terhadap kesehatan bila dikonsumsi.

Timbal $(\mathrm{Pb})$ yang masuk ke dalam tubuh dapat menyebabkan terjadinya accidental poisoning dimana dalam konsentrasi tinggi dapat mengakibatkan gejala keracunan timbal seperti iritasi gastrointestinal akut, rasa logam pada mulut, muntah, sakit perut, dan diare (Suyanto dkk., 2010). Efek negatif keracunan timbal kronis pada manusia terdiri atas penurunan kesuburan (jantan dan betina), keguguran dan kelahiran prematur, masalah kecerdasan, hipertensi, penyakit kardiovaskuler, lebih agresif, serta gangguan fungsi ginjal (Adhani dan Husaini, 2017). Tingginya cemaran mikroba dan logam timbal dalam daging langkitang dapat berdampak negatif bagi tubuh sehingga dibutuhkan pengolahan yang benar sebelum daging langkitang dikonsumsi.

\section{SIMPULAN}

Hasil pengujian bakteriologis dan deteksi logam berat menunjukkan bahwa cemaran mikroba dan logam Timbal $(\mathrm{Pb})$ pada daging langkitang yang telah melampaui ambang batas kesehatan sehingga dibutuhkan pengolahan yang tepat sebelum daging langkitang dikonsumsi.

\section{DAFTAR PUSTAKA}

Adhani, R, dan Husaini. 2017. Logam Berat Sekitar Manusia. Banjarmasin; Lambung Makurat University Press.

Febrita, E., Darmawati., dan Astuti, J. 2015. Keanekaragaman Gastropoda dan Bivalvia Hutan Mangrove sebagai Media Pembelajaran pada Konsep
Keanekaragaman Hayati Kelas X SMA. Jurnal Biogenesis, 11(2):119-128.

Ismarti, F. Amelia, dan Ramses. 2015. Kandungan Logam Berat $\mathrm{Pb}$ dan Cd pada Sedimen dan Kerang di Perairan Batam. Jurnal Dimensi, 4(3): 1-8.

Katon, MR., A. Solichin, OE. Jati. 2020. Analisis Pendugaan Bakteri Escherichia coli pada Kerang Hijau (Perna viridis) di Morosari, Demak. Journal of Maquares, 9(1): 40-46.

Mujahid, TY., K. Siddiqui, RZ Ahmed, SA. Subhan, ST. Ali, dan A. Wahab. 2015. Bacteriological Quality Analysis of Tap Water of Karachi, Pakistan. International Journal of Advanced Research, 3(2): 573-578.

Megahati, RRP. 2017. Bakteri Termofil Penghasil Selulase Asal Sumber Air Panas di Indonesia. Jurnal Bioconcetta, 3(1): 61-68.

Saenab, S., Nurhaedah, dan C. Muthiadin. 2014. Studi Kandungan Logam Berat Timbal pada Langkitang (Faunus Ater) di Perairan Desa Maroneng Kecamatan Duampanua Kabupaten Pinrang Sulawesi Selatan. Jurnal Bionature, 15 (1) : 29-34.

Supriatno dan Lelifajri. 2009. Analisis Logam Berat $\mathrm{Pb}$ dan $\mathrm{Cd}$ Dalam Sampel Ikan Kerang Secara Spektrometri Serapan Atom. Jurnal Rekasa Kimia, 7(1):5-8.

Suyanto, A., S. Kusmiati, dan Ch. Retnaningsih. 2010. Residu Logam Berat Dalam Daging Sapi yang Dipelihara di Tempat Pembuangan Sampah Akhir. Jurnal Pangan Dan Gizi, 1 (1) : 15-23. 
Utari, LK,. Riyanti, RR. dan Santosa, P. E. 2016. Status Mikrobilogis Daging Broiler di Pasar Tradisional Kabupaten Pringsewu. Jurnal Ilmiah Peternakan Terpadu, 4(1): 63-66.

Werdiningsih, W., Widyastuti, S., Nazaruddin, dan Handayani, BR. 2014. Kajian Penggunaan Asap Cair terhadap Mutu Ayam Bakar Taliwang. Jurnal Ilmiah Rekayasa Pertanian dan Biosiste, 2 (1): 2932.
Wibawa, A. 2008. Faktor Penentu Kontaminasi Bakteriologik Pada Makanan Jajanan di Sekolah Dasar. Jurnal Kesehatan Masyarakat Nasional, 3 (1): 3-8.

Zeswita, AL. dan E. Safitri. 2015. Karakter Morfometrik Pensi (Corbicula moltkiana Prime) pada Dua Ekosistem yang Berbeda. Jurnal Bioconcetta, 1(2): 49-58 